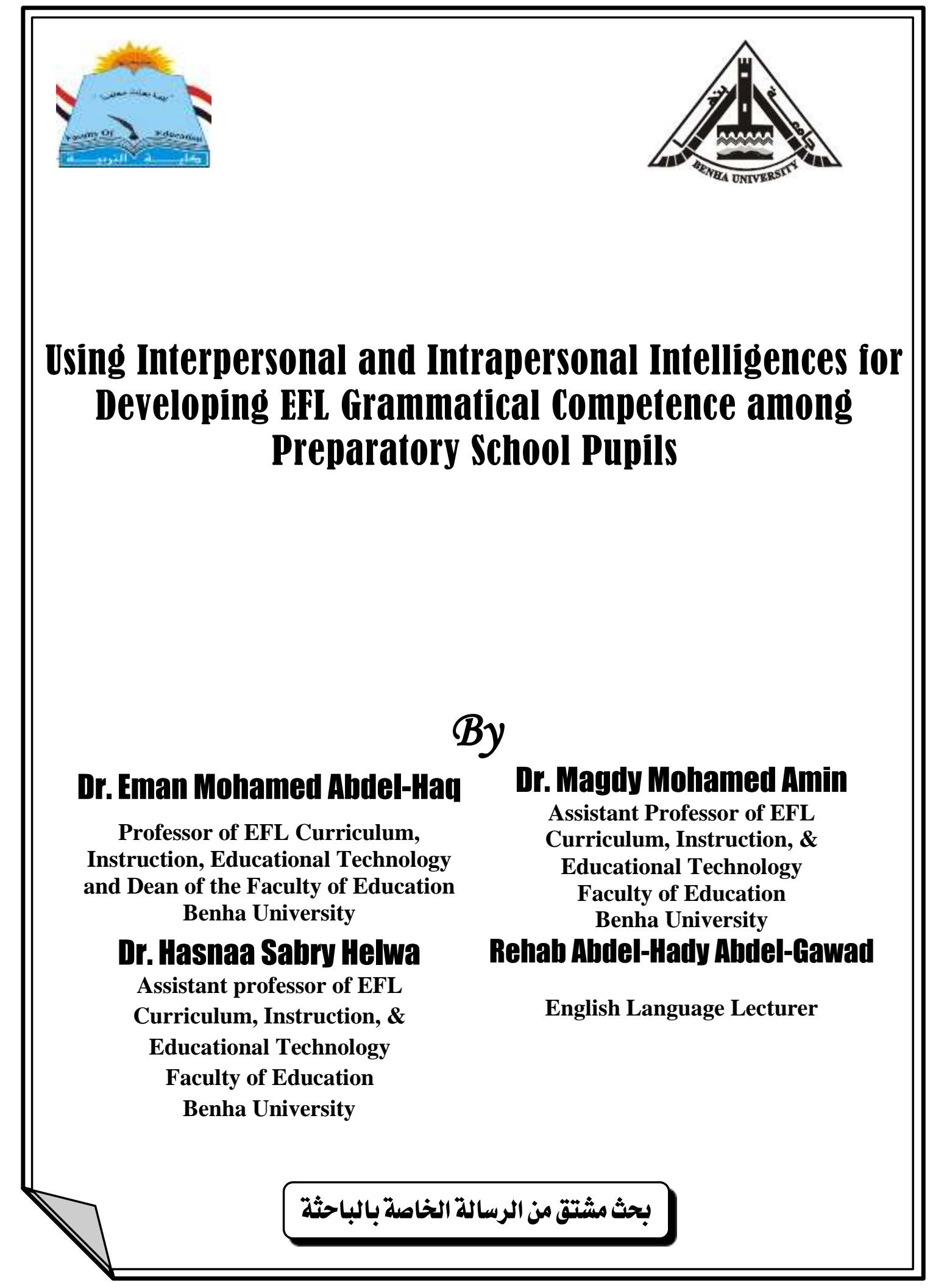




\section{Using Interpersonal and Intrapersonal Intelligences for Developing EFL Grammatical Competence among Preparatory School Pupils}

\author{
By \\ Dr. Eman Mohamed Abdel-Haq \\ Professor of EFL Curriculum, Instruction, \\ Educational Technology \\ and Dean of the Faculty of Education \\ Benha University \\ Dr. Hasnaa Sabry Helwa \\ Assistant professor of EFL \\ Curriculum, Instruction, \& Educational \\ Technology \\ Faculty of Education \\ Benha University
}

\section{Abstract}

This research aimed at improving some EFL grammatical competence among first year preparatory school pupils through using interpersonal and intrapersonal intelligences. The participants of the study consisted of 30 first year preparatory school pupils in Alshahid Mahmoud Abdelazim Mahmoud preparatory School, in Kafr Farsis, Benha, Qaliupia Government. The research followed the two-groups (experimental and control groups) pre-post test design. The Pre grammatical competence test was administered to the two groups of first year preparatory school pupils. The pupils were taught using interpersonal and intrapersonal intelligences to develop their grammatical competence skills. Then, the post-test was administered again. T-test was used to compare the mean scores of the experimental group and control group of the pre-post test. Results of the analysis revealed that the participants' EFL grammatical competence skills of the experimental group improved significantly than the control group as a result of using interpersonal and intrapersonal intelligences. Therefore, it can be concluded that the interpersonal and intrapersonal intelligences was effective in developing EFL first year preparatory school pupils' grammatical competence skills.

Keywords: EFL grammatical competence skills, Interpersonal intelligence, Intrapersonal intelligence. 


\section{Introduction:}

Language is the core of the communication between people. It is a means to transform information and knowledge to each other. Language is divided into skills and systems. Language skills are listening, speaking, reading, and writing. Language systems are phonological, syntactic, semantic, and pragmatic. Learners ought to know language systems and language skills to be versed of using language. This knowledge is important to develop and improve their language.

Knowing a language is not only knowledge its correct usage, but also followed by actual usage of this knowledge in reading, writing and other communication skills. Knowledge of grammar is easier than its usage. Knowledge alone is not enough for correct usage. Therefore, the language learner must have not only the language ability learners need to acquire. The ability to use the language was called competence (AbdelHack, 1988) ${ }^{(*)}$.

Grammatical Competence is one of the four communicative competences (grammatical competence, sociolinguistic competence, discourse competence and strategic competence). It refers to knowledge of syntax, meaning, vocabulary, and machanics. This type of competence is important because it provides skills and knowledge so that students can learn to be understood in listening, speaking, reading, and writing. The goal is to acquire knowledge of, and ability to use, forms of expression that are grammatically correct and accurate. Grammatical competence acts to promote accuracy and fluency in second/ foreign language production and increases in importance as the learner advances in proficiency (Stern, 1983; Díaz-Rico and Weed, 2010).

(*) The researcher followed the APA style of documentation. 
The proponents of grammar teaching argue that some focus on form may well be necessary for many students to achieve accuracy as well as fluency in their acquisition of a second or foreign language. The fact that the main objective of learning a language is to use it as a means of communication makes grammar essential. Grammatical competence is one of communicative competence. Communicative competence involves knowing how to use the grammar and vocabulary of the language to achieve communicative goals, and knowing how doing this in a socially appropriate way. Communicative goals are the goals of students' studying English language. So grammar teaching is necessary to achieve the goals of communicative competence (Zhang, 2009).

Morever, Helwa (2013) clarified that grammatical competence is the ability to perform the grammatical well-formedness, recognize the lexical, morphological, syntactic and phonological features of a language to form words and sentences. It refers to the knowledge of the language that accounts students' ability to produce sentences in a language and the knowledge of the building blocks of sentences (e.g. parts of speech, tenses, phrases, clauses, and sentences patterns and how sentences are formed). It is an important dimension of language learning and the ability to understand and produce the language correctly. It is concerned with producing grammatical utterances.

Some main principles for teaching grammar to learners through: the learning load should be manageable in a way that simplifies the grammar for beginning learners, as they only have a partial understanding at this stage. Therefore, it was suggested implementing consciousness-raising activities because it helps them to notice patterns and regularities that can 
be developed over time. And, it is to emphasize inductive approach over deductive approach, because of the lack of linguistic ability to comprehend grammatical explanations at the beginning stages (Nunan, 2005).

There are two good reasons for teaching grammar that are: the fact that grammar allows advanced refinement of meaning ensuring greater comprehensibility. And the other that grammar gives a learner a better chance of integration, diminishing the risk of rejection by the target language society one aspires to. Hence, grammar rules are considered as a means of controlling. This controlling does not know by those who possess expert knowledge in the dimension of both the language classroom and the underlying educational philosophy in authoritarian societies. This favor is obeying rules over the ability to express oneself (Swan, 2002).

Thus, with the advent of communicative competence theories, grammatical competence was no longer viewed as the only prerequisite of successful second language learning. Nevertheless, most language theorists have agreed that grammatical competence is a keystone for the development of communicative competence in a second or foreign language. Grammatical competence plays an important role in the learners' development of competence in a second or foreign language. Grammatical competence develops in a natural way, the way children develop grammatical competence in their native language, without the use of formal instruction (Melendez, 1993).

Consequently, through the previous studies and literatures (Melendez, 1993; Wu, 2003; Fiori, 2005; Ozkan, 2011; loaiza, 2014), assessing EFL grammatical competence divided into know (recognition) 
grammatical competence aspects and usage (production) its aspects. To measure this knowledge and usage, test will divided into sub-tests oral and written test language that included the focal grammatical points. The written test would divide into three sections (grammatical Knowledge, vocabulary knowledge, and phonology knowledge). Each section will divided into sub- questions. The oral test will prepare by the research and will record.

Since Grammatical Competence is one of the most important and problematic skills for language learners. Since advances in using many theories are widely spread for learning, the problem of competence of grammatical skills seems more manageable through using interpersonal and intrapersonal intelligences to improve grammatical competence skills. The following section sheds the light on and its uses for developing interpersonal and intrapersonal intelligences grammatical competence skills.

Gardner's Multiple Intelligences Theory, addresses how the brain deals with information, stating that there are nine different ways by the brain in thinking, solving problems, and learning. Even though it is a theory and has yet no specific application method or instructional approach, it does offer a structure by which to develop the student and pedagogical model for teaching. Multiple intelligences theory suggests that there is not just one concrete measure of intelligence and by implication not just one single way of teaching. Hence, Gardner suggests that learning and teaching can be understood and practiced through many avenues. He started with intelligences in 1983 (Sahatsatatsana \& Siriyothin, 2010). 
It is of the utmost importance that was recognized and nurture all of the varied human intelligences and all of the combinations of intelligences. Learners are all so different largely because they have different combinations of intelligences. If they recognize this, they will have at least a better chance of dealing appropriately with the many problems that they face in the world. If they can mobilize the spectrum of human abilities, not only will people feel better about themselves and more competent; it is even possible that they will also feel more engaged and better able to join the rest of the world community in working for the broader good(Gardner, 2006).

According to (Christison \& Kennedy, 1999), four ways were identified in which the MI theory can be used in the classroom as following;

- As a tool to help students develop appreciation of their own strengths and their preferred ways of learning.

- As a tool to develop a better understanding of learners' intelligences.

- As a guide to provide a greater variety of ways for students to learn and to demonstrate their learning.

- As a guide to develop lesson plans.

Many researchers such as Armstrong (2009), Gardner (1983, 2006), Fleetham (2006), Ibnian ,\& Hadban (2013), lazear (2000), Nelson (1998), Palmberg (2011) mentioned that, Gardner (1983) listed seven intelligences; verbal/ linguistic, bodily/ kinesthetic, logical/mathematical, visual/spatial, musical, interpersonal, and intrapersonal intelligence. Addition to, in 2006, he added three intelligences; natural, spiritual and existential intelligence. 
In this study will use two intelligences (Intrapersonal intelligence and intrapersonal intelligence).

\section{Interpersonal Intelligence:}

This intelligence is the ability to understand and discern the feelings and intentions of others. This can include sensitivity to facial expressions, voice, and gestures; the capacity for discriminating among many different kinds of interpersonal cues; and the ability to respond effectively to those cues in some pragmatic way (e.g., to influence a group of people to follow a certain line of action) (Gardner, 1983, 2006; Nelson,1998; lazear,2000; Fleetham, 2006; Armstrong,2009; Palmberg,2011; Ibnian ,\& Hadban,2013).

\section{Intrapersonal Intelligence:}

This intelligence is the ability to understand one's own feelings and motivations. These two intelligences are separate from each other. Nevertheless, because of their close association in most cultures, they are often linked together. It includes having an accurate picture of oneself (one's strengths and limitations); awareness of inner moods, intentions, motivations, temperaments, and desires; and the capacity for self-discipline, self-understanding, and self-esteem (Gardner, 1983, 2006; Nelson, 1998; lazear, 2000; Fleetham, 2006; Armstrong,2009; Palmberg, 2011; Ibnian , \& Hadban,2013).

Strategies to stimulate the intelligences according to: (Nelson,1998; Gardner, 2006; Armstrong, 2009; Palmberg,2011; Ibnian \& Hadban, 2013); Here are five strategies for Interpersonal intelligence as following: 
(Peer Sharing, People Sculptures, Cooperative Groups, Board Games Simulation). And, Here are five strategies for Intrapersonal intelligence as following:(One Minute Reflection, Personal Connections, Feeling- Toned Moment Choice Time, Goal- Setting Sessions).

Zarie and Mohseni (2012) investigated the relationship between four types of intelligence (logical, interpersonal, verbal and intrapersonal) and grammatical and writing accuracy of foreign language learners. This study employed a 40-item multiple intelligence questionnaire, a 35-item Michigan grammar test and a writing test. The sample was 190 male and female Iranian students at Takestan Azad University, Karaj Azad University, and Imam khomeini International University in Qazvin. The results showed that both intrapersonal and interpersonal intelligence were predictors of grammar accuracy and intrapersonal intelligence made a statistically significant contribution to predicting learner's writing accuracy.

\section{Context of the Problem}

Students' mastery of a language is ultimately measured by how well they can use it not by how much they know about it. In spite of the importance of grammatical competence for the preparatory stage pupils, it has not been given enough attention. Unfortunately, it is considered as unimportant aspect in the language learning process that does not deserve enough attention. The result is an apparent weakness in first-year pupils' grammatical competence learning that affects badly their learning language.

According to the importance of grammatical competence the standards of the Egyptian Ministry of Education and the aims of the 
English course in the first-year at preparatory stage (2012); pupils should be prepared to be aware of the following:

- Use and explain synonyms and antonyms.

- Use basic prefixes to infer word meaning.

- Identify and explain meaning of phrasal verbs.

- Identify nouns and pronouns and their reference.

- Identify and use compound sentence patterns (affirmative).

- Use simple and complex grammatical structures to communicate meaning.

- Use functional rules appropriately determiners (e.g., articles, demonstratives), prepositions and reflexive pronouns.

- Use correct sentence word order.

- Use technology resources (internet and electronic dictionaries) to practice language structure.

It can be stated that the lack of grammatical competence itself through the Egyptian studies such as Abdel-Samiaeli (1992), Hegazy (2008), Helmy (2008), Soliman (2008), Mohammed (2011), Elbasel (2012) and Salam (2013) which they stated that there is a lack in the current Egyptian English language programs which do not concern in how to provide pupils with enough opportunities to practice grammar in a correct way. Moreover, they argued that the poor grammatical competence of preparatory stage pupils lies in the lack of attention given to its teaching in the Egyptian preparatory stage and that pupils' grammatical mistakes are so common and their grammatical competence 
are unintelligible. Therefore, pupils are only taught the basic information that can help them to pass their grammar exams.

To document the problem of the study, a pilot study was conducted by the researcher to find out the lack of grammatical competence among first-year pupils at preparatory stage. The participants were 50 pupils at AlShahid Mahmoud Abdelazim Mahmoud preparatory school, Kafr Farsis, Benha educational administration. The pilot study consisted of grammatical competence test. This test comprises of five questions to show pupils' ability in using past simple, future, prepositions, comparative, adjectives, asking questions, verbs, punctuation and writing short sentences. The results of the pilot study revealed that about $80 \%$ pupils did not master these aspects. To face search a problem, the researcher will attempt to use multiple intelligence theory to develop EFL grammatical competence among first-year pupils at preparatory school.

\section{Statement of the Problem}

In spite of the importance of EFL grammatical competence, there is a lack in EFL grammatical competence among first- year pupils at preparatory stage. Therefore, the present research aims at using interpersonal and intrapersonal intelligences for developing EFL grammatical competence skills among first-year pupils at preparatory stage.

\section{Questions of the Research}

To investigate this problem, the present attempted to answer the following questions:

1- What is The EFL grammatical competence skills required for firstyear pupils at preparatory stage? 
2- How can interpersonal and intrapersonal intelligences are used for developing EFL grammatical competence skills among first-year preparatory stage pupils?

3- What is the effectiveness of using interpersonal and intrapersonal intelligences in developing EFL grammatical competence skills among first-year pupils at preparatory stage?

\section{Delimitations of the Research}

This research was delimited to:

1- First year preparatory school pupils as pupils are neither old nor young to apply the program of multiple intelligences strategies.

2- Some grammatical competence skills appropriate for first year preparatory school.

3- Interpersonal intelligence and Intrapersonal intelligence.

\section{Research Methodology}

This research utilized the experimental design known as the twogroups experimental and control group design.

\section{Participants of the Research}

The participants of the present research consisted of two groups (experimental and control groups) of first year preparatory stage pupils each group ( $\mathrm{n}=30)$ at Elshahid Mahmoud Abdelazim Mahmoud preparatory School, Kafr Farsis, Benha, Qaluipia Governorate, during the academic year 2018/2019.

\section{Instruments and Materials of the Research}

\section{A) A pre-post EFL grammatical competence skills test.}

The EFL grammatical competence skills test was designed to measure the 19 sub-skills assigned as very important by the jury 
members. Three parts were assigned to measure main skills. The test includes a total number of 34questions in three parts as following:

1- Part "A": aims at measuring grammatical skills and consisted of three questions (multiple choices question, mini dialogue, and underlined the mistake).

2- Part "B" aims at measuring vocabulary skills and consisted of two questions (multiple choices question, and underlined the mistake).

3- Finally part "C" aims at measuring phonology skills and consisted of two questions (pronounce phrases, and describe the picture).

The test was submitted to jury members in Curricula and Methods of Teaching English $(n=8)$. They were asked to indicate the suitability of the test content for the first year preparatory stage pupils and the clarity of the instructions for each part of the test. They indicated the suitability of the test items to assess the skills intended

\section{B) A rubric of EFL grammatical competence skills.}

The rubric was used to score the pupils' performance in the EFL grammatical competence test. The rubric consists of one part scored (phonology skills) on a three points Likert scale ranging from "3" to "1" marks. The students are given a rating between "1" to "3" for their performance in the EFL phonology skills. The pupils are given "3" marks when they pronounce correctly. They are given "2", if they have some mistakes. And they are given "1" mark when they don't pronounce.

For estimating the reliability of the EFL grammatical competence test, Alpha Cronbach coefficient and test-retest method were used. The test was administered to a group of 1 st year preparatory school pupils at 
Alshahid Mahmoud Abdelazim Mahmoud preparatoery school, Kafr Farsis, Benha, Qaliupia Governorate (other than experimental and control groups who received the treatment) during the first semester of the academic year 2018/2019. Then, it was administered to the same group again after two weeks. The Pearson correlation coefficient between the two administrations was (.927) which is significant at the (0.01) level. This means that the EFL grammatical competence pre-post test is reliable.

\section{The Intervention}

A teacher's guide was designed to explain in details how interpersonal and intrapersonal intelligence can be used for developing EFL grammatical competence skills. Twenty one sessions were prepared. Each session, the teacher would follow two stages. In first stage, he/she divide the class into 6 groups each group contains of 5 pupils. Each group will choose one of them to be a leader and responsible for works of his/her group. Teacher would use two strategies (Peer sharing - Cooperative groups) during this stage. In second stage, Pupils would work individually. Teacher would distribute papers (selfevaluation sheets). Pupils would answer question to evaluate themselves. Teacher would use two strategies (One minute reflection - Personal connections) during this stage.

\section{Results of the Research}

Data were statistically treated using Statistical Package for the Social Science (SPSS) program (version 22). Table (1) and (2) show the results of the study. 
Table 1: Findings of t-test of the EFL Grammatical Competence skills post- administration for experimental group and that control group

\begin{tabular}{|c|c|c|c|c|c|c|c|c|}
\hline Skill & Group & $\mathbf{N}$ & Application & Mean & S.D & $\begin{array}{c}\text { T- } \\
\text { value }\end{array}$ & D.F & Sig \\
\hline \multirow{2}{*}{\begin{tabular}{|c|} 
EFL \\
Grammatical \\
competence \\
Skills
\end{tabular}} & control & \multirow[b]{2}{*}{30} & \multirow[b]{2}{*}{ Post } & 25.300 & 5.62721 & \multirow[b]{2}{*}{8.345} & \multirow[b]{2}{*}{29} & \multirow{2}{*}{.000} \\
\hline & Experimental & & & 42.9333 & 10.11293 & & & \\
\hline
\end{tabular}

Table 2: Findings of t-test of the EFL grammatical competence postadministration in each main skill of experimental and control group

\begin{tabular}{|c|c|c|c|c|c|c|c|c|}
\hline Main skill & Group & $\mathbf{N}$ & Application & Mean & S.D & t-value & D.F & Sig. \\
\hline \multirow{2}{*}{$\begin{array}{c}\text { Grammatical } \\
\text { Skills } \\
\end{array}$} & experimental & \multirow{2}{*}{30} & \multirow{2}{*}{ Post-test } & 13.567 & 3.5495 & \multirow{2}{*}{6.333} & \multirow{6}{*}{29} & \multirow{2}{*}{000} \\
\hline & control & & & 8.333 & 2.8080 & & & \\
\hline \multirow{2}{*}{$\begin{array}{c}\text { Vocabulary } \\
\text { Skills }\end{array}$} & experimental & \multirow{2}{*}{30} & \multirow{2}{*}{ Post-test } & 13.733 & 2.9235 & \multirow{2}{*}{7.620} & & \multirow{2}{*}{.000} \\
\hline & control & & & 8.800 & 2.0069 & & & \\
\hline \multirow{2}{*}{$\begin{array}{l}\text { Phonology } \\
\text { Skills }\end{array}$} & experimental & \multirow{2}{*}{30} & \multirow{2}{*}{ Post-test } & 15.633 & 4.7524 & \multirow{2}{*}{7.514} & & \multirow{2}{*}{.000} \\
\hline & control & & & 8.167 & 2.6533 & & & \\
\hline
\end{tabular}

Table (1) shows that "There is a statistically significant difference at the (0.01) level between the mean scores of the experimental group and that of control group in EFL Grammatical Competence skills on the post administration of EFL grammatical competence skills test in favor of the experimental group".

Table (2) shows that the mean score of the experimental group in the post application of the EFL grammatical competence skills test was higher than score of the control group in the grammatical competence skills post-test in the grammatical skills; $t$-value is (6.333), which is significant at the (0.01) level. Thus, it can be said that interpersonal and intrapersonal intelligences positively affected grammatical skills among the study participants. 
Findings also indicates that the mean score of the experimental group in the post application of the EFL grammatical competence skills test was higher than score of the control group in the EFL grammatical competence skills post-administration in the vocabulary skills; $t$-value is (7.620), which is significant at the (0.01) level. Again, it can be said that interpersonal and intrapersonal intelligences positively affected vocabulary grammatical competence skills among the study participants.

Furthermore, findings indicated that the mean scores of the experimental group in the post application of the EFL grammatical competence skills test were higher than score of the control group in the EFL grammatical competence skills in the phonology skills; t-value is (7.514), which is significant at the (0.01) level. Consequently, it can be said that the participants' phonology skills has been developed as a result of using interpersonal and intrapersonal intelligences.

\section{Discussion and Interpretation of the Results}

Results of the research revealed that there was a statistically significant difference at the (0.01) level between the mean scores of the experimental group and that of control group in EFL Grammatical Competence skills on the post administration of EFL grammatical competence skills test in favor of the experimental group. Hence, it was concluded that using interpersonal and intrapersonal intelligences was effective in developing EFL grammatical competence skills. This may be attributed to different reasons. It is related to the nature of interpersonal and intrapersonal intelligences, which included some strategies and activities for developing EFL grammatical competence skills. Moreover, interpersonal and intrapersonal intelligences were helpful in providing authentic content 
to help pupils develop grammatical competence to identify the parts of sentences, apply verbs, apply correct sentences structures, use various vocabulary, putting words together, pronounce words in sequence, use rhythm and intonation.

One of the prominent advantages of interpersonal and intrapersonal intelligences that might help to develop some of pupil grammatical competence skills in this research is that it offered the researcher and pupils a wide range of possibilities for extra grammatical competence both inside and outside of the classroom. So, the researcher provided experimental group with authentic material at any time and any place to develop their grammatical competence skills. Moreover, interpersonal and intrapersonal intelligences are considered an opportunity to compensate pupils for short time of sessions. So, the teacher could extend and duplicate the sessions outside the classroom.

Another remarkable advantage of using interpersonal and intrapersonal intelligences is that helped pupils to change their concept about learning English language in general and EFL grammatical competence skills in particular. This helped them to turn from passive learners into active ones. In addition, it helped the researcher to turn from lecturer into monitor, guide and facilitator.

\section{Recommendations of the Research}

Based on the results of the present research, the following recommendations should be taken into consideration:

1- The English language teachers should use interpersonal and intrapersonal intelligences to aid pupils practice grammatical competence in a meaningful context. 
2- Teaching should be turned from being teacher-centered to learnercentered in which learners become more involved in and responsible for their learning and become self-autonomous.

3- Schools should be trained on the use of group work and (MIT) instead of traditional teaching.

\section{Suggestions for Further Research}

The results drawn from this study pointed to a need to conduct further research as follows:

1- Investigating the effect of using interpersonal and intrapersonal intelligences on improving EFL grammatical competence skills among learners at other educational levels: primary and secondary.

2- Investigating the effect of using interpersonal and intrapersonal intelligences on other language skills such as listening, speaking, reading and writing.

3- Identifying the effectiveness of using interpersonal and intrapersonal intelligences on developing listening and speaking skills among learners at different educational levels.

4- Identifying effect of a study using other types of intelligences for EFL grammatical competence is needed.

5- Investigating the effectiveness of more recent technology applications in the EFL grammatical competence skills. 


\section{References}

- Abdel-Hack, E .M. (1988). Testing Students' Knowledge Of Grammar Compared With Their Actual Usage In Their Written Work At The Secondary Stage: An Analytic Study (Unpublished Master's Thesis). Faculty Of Education Benha, Zagazig University.

- Abdel El-Samieali, M.F. (1992). The effect of using the communicative approach in teaching grammar on the oral performance of preserves teachers of English(Unpublished Master's thesis). Faculty Of Education, Cairo University.

- Armstrong, T. (2009) . Multiple Intelligences In The Classroom. 3rd Edn, ASCD, Alexandria, Virginia, USA.

- Christison, M.A; \& Kennedy. s. (1999). "A Guidebook For Applying Multiple Intelligences Theory In The ESL/EFL Classroom." Burlingame, CA: Alta Book Center

- Díaz-Rico, L. T., \& Weed, K. Z. (2010). The crosscultural, language, and academic development handbook: A complete $K-12$ reference guide (4th ed.). Boston: Allyn \& Bacon.

- Elbasel, R, A, M.(2012). A suggested social constructivisim strategy for developing first pre stage students' English grammatical performance (Unpublished master thesis). Damietta Faculty Of Education, Mansora University.

- Fiori, L, M. (2005). The Development Of Grammatical Competence Through Synchronous Computer - Mediated Communication. CALICO Journal, 22 (3), 567 - 602. 
- Fleetham, M . (2006). Multiple Intelligences In Practice Enhancing Self-Esteem And Learning In The Classroom. Stafford: Network Continuum Education.

- Gardner, H. (1983). Frames of mind the theory of multiple intelligences. New York: Basic Books.

- Gardner, H. (2006). Multiple Intelligence. New York: Basic Books.

- Hegazy, M,F,A.(2008). The effectiveness of some free linguistic activities in developing primary school pupil's use of English grammar rules (Unpublished Master Thesis). Faculty Of Education, Zagazic University.

- Helwa, H .S.A.A . (2013). The Effectiveness Of A Self-Autonomy Based Program In Developing EFL Student Teacher's Communicative Competence (Unpublished Doctoral Dissertation). Faculty Of Education, Benha University.

- Helmy, H, S, H. (2008). The effectiveness of a task-based teaching strategy on learning of grammatical structures and their use in written expression by preparatory students(Unpublished Master Thesis). Women's College, Ain Shams University.

- Ibnian ,S ,S., \& Hadban, A, D.(2013). Implications Of Multiple Intelligences Theory In ELT Field. International Journal Of Humanities And Social Science, 3 (4), 292- 297.

- Lazear, D. (2000). The intelligences curriculum. USA: Zephyr Press.

- Melendez, M, M.(1993). The Effects Of Grammar Instruction On Learners' Development Of Grammatical Competence In A Foreign Language (Doctoral Dissertation). Retrieved From Proquest Digital Dissertations. (UMI 48106). 
- Mohammed, D, A, M. (2011). The effect of using a program based on the functional grammar on enhancing EFL pre-service teachers grammatical competence, oral communicative competence and cultural awareness (Unpublished Doctoral Dissertation). Faculty Of Education, Minia University.

- Ministry of Education (2012). The National Curriculum Framework for English as Foreign (EFL) Grades 1-12, Egypt.

- Nelson, K, N. (1998). Developing Students' Multiple Intelligences. New York: Broadway.

- Nunan, D. (2005). Practical English Language Teaching: Grammar. New York: Mcgraw - Hill.

- Ozkan, Y. (2011). Assessment Of Grammatical Competence Based On Authentic Texts. International Journal Of English Linguistics, $1(2), 148-154$.

- Palmberg, R. (2011). Multiple Intelligences Revisited. Available At : Http://Www.Vasa.Abo.Fi/Users/Rpalmber/

- Sahatsatatsana, S. ; and Siriyothin, P. (2010). Integration of multiple intelligences theory in English instruction. International Journal of Educational Administration and Development, 1(2), 105-118.

- Sallam, A, A.(2013). The Effectiveness of a Corpus-Centered Program in Developing Lexicogrammatical Materials and Linguistic Competence among EFL Perspective Teachers (Unpublished Doctoral Dissertation). Faculty Of Education, Damanhour University.

- Soliman, R, F, A, H.(2008). The use of some language activities in developing grammatical performance of primary stage pupils and their attitudes towards these activities ( Unpublished Master thesis). Faculty Of Education, Mansora University. 
- Stern, H.H.(1983). Fundamental Concepts of Language Teaching. Oxford: Oxford University Press.

- Swan, M. (2002). Seven Bad Reasons For Teaching Grammar And Two Good Ones.In :Jack C. Richards And Willy A. Renandya (Eds.).Cambridge University Press. PP: 148-154.

- Wu, Y. (2003). The Effect Of Language Learning Strategies On Colege-Level EFL Students' Grammatical Competence In Taiwan(Doctoral Dissertation). Retrieved from Proquest Digital Dissertations. (UMI3089856).

- Zarei, A,A \& Mohseni, F .(2012). On the Relationship Between Multiple Intelligences and Grammatical and Writing Accuracy of Iranian learners of English. US-China Foreign language, 10 (7).1306-1317. 
استخدام الذكاء الشخصى والذكاء الاجتماعى لتنمية مهارات الكفاءة الندوية

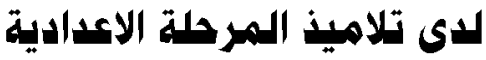

\section{مستخلص البحث}

هدف هذا البحث الـى تتميـة الكفـاءة النحويـة لـدى طـلاب الصـف الاول الاعدادى

بمدرسة الثهيد محمود عبدالعظيم محمود الاعدادية بكفر فرسيس، بنها، القليوبية وذلك باستخدام الـذكاء الثخصـى والـذكاء الاجتمـاعى • وقـد تـم اسـتخدام البرنـامجى التجريبـى القـائم على مجموعتين (مجموعة تجريبية ومجموعة ضـابطة). وبلغت عينة الدراسـة ثلاثون طالبة وطالبة لكل مجموعة على السواء. وتم تصميم قائمـة بالمهارات اللازمـة لهؤلاء الطلاب. وتم تصميم اختبار قبلى وبعدى لقياس الكفاءة النحوية. تم اختبار الطلاب قبليا لتحديد مستوى ادائهم القبلى وتدريبهم من خلال استخدام الذكاء الثخصى والذكاء الاجتماعى على مهارات الكفاءة النحويـة. وتم تطبيق الاختبار مرة ثانية (بعديا) على المجموعتين التجريبة والضـابطة لقياس مدى التقدم في مستوى اداء المجموعتين. ولقد اثبتت النتائج وجود فرق فى اداء الطـلاب فى المجموعـة التجريبة والمجموعة الضـابطة فى الاختبار البعدى لصالح المجموعة التجريبية مما يدل على فاعلية استخدام الذكاء الشخصى والذكاء الاجتماعى فى تتمية مهارات الكفاءة النحوية. كلمات مفتاحية: مهارات الكفاءة النحوية، الذكاء الشخصى، الذكاء الاجتماعى 